\title{
Medical students' perception of international health electives in the undergraduate medical curriculum at the College of Medicine, King Saud University
}

This article was published in the following Dove Press journal:

Advances in Medical Education and Practice

\author{
Abdullah Fouda Neel' \\ Leena Saad AlAhmari \\ Reema Ayed Alanazi ${ }^{3}$ \\ Kamran Sattar ${ }^{4}$ \\ Tauseef Ahmad ${ }^{4}$ \\ Elizabeth Feeley ${ }^{4}$ \\ Mahmoud Salah Khalil ${ }^{4}$ \\ Mona Soliman ${ }^{4}$ \\ 'College of Medicine, Alfaisal \\ University, Riyadh, Saudi Arabia; \\ ${ }^{2}$ Department of Family Medicine \\ and Polyclinics, College of Medicine, \\ King Saud University, Riyadh, Saudi \\ Arabia; ${ }^{3}$ College of Medicine, King \\ Saud University, Riyadh, Saudi Arabia; \\ ${ }^{4}$ Department of Medical Education, \\ College of Medicine, King Saud \\ University, Riyadh, Saudi Arabia
}

Background: International health electives prepare medical students during their student years of medical education in choosing, matching, and succeeding in the residency of their choice. They serve as a unique educational experience prior to residency training.

Objective: This study was conducted to explore 4th- and 5th-year medical students' perspective about international health electives and to evaluate their educational effects.

Methods: An anonymous online survey with 22 items concerning perceptions about the electives with a 5-point Likert scale was administered to medical students at the College of Medicine, King Saud University.

Results: For the majority of the students $(81.6 \%)$ the elective course was arranged by the university and only $18.4 \%$ of students individually arranged their own. Most of the students $(65.7 \%)$ agreed that the objective of the elective course was clear to them in advance. A total of $71.1 \%$ of students agreed that the program (elective) was responsive to their needs (both academically and socially).

Conclusion: This is the first study looking at international electives in the context of the undergraduate medical curriculum in Saudi Arabia. The study showed that the international electives are a useful and unique experience for medical students (both academically and socially).

Keywords: medical students, perception, international electives, experience, Saudi Arabia

\section{Introduction}

International health electives (IHEs) are a popular component of many medical school and residency program curricula and are reported to have positive educational influences on participants' knowledge, skills, and attitudes. Electives can contribute to both the professional and individual progress of medical students in specific areas of interest outside of the regular curriculum. ${ }^{1-3}$

Many US and Canadian medical students and residents select to devote part of their training in international settings. In a survey of 2,000 graduating US and Canadian medical students, the Association of American Medical Colleges reported that over $38 \%$ had participated in an international health experience. ${ }^{4}$

IHEs stated to offer learning assistances in knowledge (eg, cross-cultural matters, as well as health care delivery), enriched skills (eg, problem-solving, clinical examination, as well as language), and nurturing certain attitudes and values (eg, community service and humanism), and all such academic benefits appeared to be mutually beneficial for the sending institutions and host hospitals..$^{5-9}$ Moreover, majority of elective participants in an IHE gained knowledge especially if there were ample measures from the
Correspondence: Mona Soliman Department of Medical Education, College of Medicine, KSU, PO Box 29825 (29), Riyadh II 46 I, Saudi Arabia

Tel +96650546858I

Email msoliman I@ksu.edu.sa 
sending institutes concerning the preparation and organization for electives. ${ }^{10}$ IHEs also appear to be associated with ethical learning, choosing careers, as well as with a positive influence on clinical diagnostic skills. ${ }^{10,11}$

As the College of Medicine continues to develop and implement the new curriculum, it seeks to provide students with opportunities to work in diverse environments, gain a deeper understanding of the relationships between medicine and culture, both share experiences and learn from others, as well as learn the disciplines that will equip them to become better physicians.

The purpose of the College of Medicine Elective Program is to create a student-centered approach to education by allowing undergraduate students to widen their learning across different academic arenas and to excavate their knowledge and encouraging them to follow their interests. ${ }^{12,13}$ Most students will be taking their elective within King Saud University (KSU), but some have also secured and self-funded positions abroad in approved institutions. A third group has been selected and will be funded by the university. Main learning outcomes during the electives at KSU aim to enable the students to gain a deeper appreciation of a physician's role in a given context, either clinical or research, as well as to develop proactive learning strategies, and share within the medical profession whether in a local or international elective. Duration of stay in the elective program surveyed ranged from 4 to 12 weeks.

\section{Methods}

This was a cross-sectional study. The perceptions of participating students in this study were assessed by means of a survey questionnaire, comprising of total 30 items in the English language.

\section{Study instrument}

An anonymous, self-administered, English language questionnaire with 30 survey items was used for gathering the participants' answers. Out of the total 30 items, there were 4 items, in Table 1, for demographics; 4 items, in Table 2, concerning mainly about arrangement, specialty chosen, and country of elective; 19 items, in Table 3, seeking students' responses on a 5-point Likert scale from strongly agree to strongly disagree; and, Table 4, was an open-ended question, asking participants for their wish to recommend the elective and to record their experiences during the elective. The medical class graduating in the year 2015 was surveyed immediately prior to and shortly after their elective experience and, for that, an online survey using a face validated questionnaire which was developed by the authors after a series of students and staff focus group discussions was used. The questionnaire included demographic data, administrative support data, and evaluation feedback that were answered anonymously and consisted of 30 items with 5-point Likert scale questions. The questionnaire was sent to the students who had taken part in the 4-week electives in May 2016 via Google documents. The items asked were related to the students' perceptions of the value of the elective, their interest in a career in medical research, and the skills acquired from the elective. The survey was developed in collaboration with experts in medical education and medical students involved in the elective. It was pilot tested on a sample of students for clarity and construct validity.

\section{Research participants}

The questionnaire was sent to a total number of 38 students who had taken part in the 4-week electives in May 2016. Out of a total 38 respondents, 29 (76.3\%) were from 4th year, 9 $(23.7 \%)$ from 5 th year. All of these medical students were communicated with through their emails and were asked to participate in this study.

\section{Selection criteria}

The elective program at College of Medicine, KSU, is compulsory for the year 4 and 5 medical students. For the students willing to go abroad for the international elective, it is required to pass through selection criteria consisting of a submission form for registration and then an initial interview. The final decision for the selection is made on the basis of students' grade point average (GPA), his/her English speaking skills, and any prior research publication.

Initially, 235 students both from the year 4 and 5 had submitted their registration form, depending on the qualifying criteria (ie, completely filling the form and timely submission to the concerned personnel), but only 110 students were

Table I Demographics

\begin{tabular}{|l|l|l|}
\hline Factor & Categories & $\begin{array}{l}\text { Number } \\
\text { (\%) }\end{array}$ \\
\hline Gender & Male & $14(36.8)$ \\
My year of study at the time & Female & $24(63.2)$ \\
of AMC elective & 4 th & $29(76.3)$ \\
Was the elective compulsory & 5 th & $9(23.7)$ \\
(4th- and 5th-year students) & Yes & $38(100)$ \\
\hline
\end{tabular}

Abbreviation: AMC, Asan Medical Center. 
Table 2 Items concerning the general arrangement of electives

\begin{tabular}{|c|c|c|}
\hline Item & Categories & Number (\%) \\
\hline How was the elective arranged? & $\begin{array}{l}\text { Individual } \\
\text { University }\end{array}$ & $\begin{array}{l}7(18.4) \\
31(81.6)\end{array}$ \\
\hline I have come to know about the elective program through $[\ldots]$ ? & $\begin{array}{l}\text { Faculty at university } \\
\text { Fellow abroad } \\
\text { Meet a faculty at the conference } \\
\text { Previous students } \\
\text { Website information }\end{array}$ & $\begin{array}{l}16(42.1) \\
2(5.2) \\
1(2.6) \\
11(28.9) \\
8(2 I)\end{array}$ \\
\hline What speciality were you in? & $\begin{array}{l}\text { Anesthesia } \\
\text { Cardiac surgery } \\
\text { Cardiology } \\
\text { Colorectal surgery } \\
\text { Emergency medicine } \\
\text { ENT } \\
\text { GS } \\
\text { Gyn } \\
\text { HPB } \\
\text { Neurosurgery } \\
\text { Ophthalmology } \\
\text { Otolaryngology-head and neck surgery } \\
\text { Pediatric orthopedic } \\
\text { Plastic surgery } \\
\text { Radiology }\end{array}$ & $\begin{array}{ll}2(5.3) \\
4(10.4) \\
3(7.9) \\
2(5.2) \\
3(7.9) \\
3(7.9) \\
3(7.9) \\
4(10.5) \\
2(5.2) \\
2(5.2) \\
4(10.4) \\
2(5.2) \\
2(5.2) \\
4(10.5) \\
1(2.6) \\
\end{array}$ \\
\hline Did you travel alone or with a family member? & $\begin{array}{l}\text { Alone } \\
\text { Family member }\end{array}$ & $\begin{array}{l}24(63.2) \\
14(36.8)\end{array}$ \\
\hline Someone was assigned to assist me (during my electives) & $\begin{array}{l}\text { Yes } \\
\text { No }\end{array}$ & $\begin{array}{l}38(100) \\
0(0) \\
\end{array}$ \\
\hline Country of elective & $\begin{array}{l}\text { Korea } \\
\text { Canada } \\
\text { UK } \\
\text { France }\end{array}$ & $\begin{array}{l}18(47.36) \\
13(34.21) \\
3(7.89) \\
4(10.52)\end{array}$ \\
\hline
\end{tabular}

Abbreviations: ENT, ear-nose-throat; GS, general surgery; Gyn, gynecology; HPB, Hepato-Pancreatico-Biliary.

called for an initial interview. Out of this total, 60 students arrived on the interview date/time. These students were interviewed by a team of experts comprising of 3 medical educationists, who also considered the candidates' suitability for international electives depending on the GPA and interpersonal and linguistic skills; hence, 39 students were finally selected.

\section{Settings}

We conducted this study at the College of Medicine, KSU, during the academic year 2015-2016.

\section{The methods of data collection}

All students documented their answers for the survey anonymously. The survey also comprised of a written informed consent from the participants. The Department of Medical Education, College of Medicine, KSU, permitted this study. All participants were sent two reminder emails with a gap of a week.

\section{Data analysis}

The data acquired from the study were entered into Microsoft Excel 2007 (Microsoft Corporation, Redmond, WA, USA) and analyzed by means of the IBM SPSS Program. A $P$-value of $<0.05$ was considered to be statistically significant.

\section{Results}

Table 1 represents the demographic information of elective course. A total of 38 students participated in the elective course during the year 2016. Of them, 14 (36.8\%) were male and $24(63.2 \%)$ were female students. All $38(100 \%)$ of the participating students agreed that the elective they took was compulsory in year 4 and 5 medical years.

Table 2 summarizes the six items concerning the elective course. The students' overall response showed that for the majority of the students, ie, $31(81.6 \%)$, the elective course was arranged by the university and only 7 (18.4\%) of students individually arranged it on their own. Most of the students, 24 
Table 3 Students' perception on elective

\begin{tabular}{|c|c|c|c|c|c|c|c|}
\hline Items & $\begin{array}{l}\text { Mean } \\
\pm \text { SD }\end{array}$ & $\begin{array}{l}\text { Strongly } \\
\text { agree, } \\
\text { n (\%) }\end{array}$ & $\begin{array}{l}\text { Agree, } \\
\text { n (\%) }\end{array}$ & $\begin{array}{l}\text { Do not } \\
\text { know, } \\
\text { n (\%) }\end{array}$ & $\begin{array}{l}\text { Disagree, } \\
\text { n (\%) }\end{array}$ & $\begin{array}{l}\text { Strongly } \\
\text { disagree, } \\
\text { n (\%) }\end{array}$ & $\begin{array}{l}\chi^{2} \\
\text { (P-value) }\end{array}$ \\
\hline $\begin{array}{l}\text { Adequate information was provided } \\
\text { to me in advance as what to expect } \\
\text { during elective. }\end{array}$ & $3.34 \pm 1.12$ & $5(13.2)$ & $14(36.8)$ & II (28.9) & $5(13.2)$ & $3(7.9)$ & $8.63(0.37)$ \\
\hline $\begin{array}{l}\text { Arrangements were appropriate } \\
\text { in terms of housing, food, and } \\
\text { transportation. }\end{array}$ & $4.26 \pm 0.95$ & $20(52.6)$ & II (28.9) & $4(10.5)$ & $3(7.9)$ & $0(0)$ & $3.85(0.69)$ \\
\hline $\begin{array}{l}\text { The objectives of the electives were } \\
\text { clear to me in advance. }\end{array}$ & $3.66 \pm 1.25$ & II (28.9) & $14(36.8)$ & $5(13.2)$ & $5(13.2)$ & $3(7.9)$ & $7.97(0.43)$ \\
\hline $\begin{array}{l}\text { The program was responsive to } \\
\text { my needs? (both academically and } \\
\text { socially). }\end{array}$ & $3.79 \pm 1.18$ & $12(31.6)$ & $15(39.5)$ & $4(10.5)$ & $5(13.2)$ & $2(5.3)$ & $5.54(0.69)$ \\
\hline $\begin{array}{l}\text { I had adequate supervision during } \\
\text { clinical training. }\end{array}$ & $3.21 \pm 1.3$ & $7(18.4)$ & II (28.9) & $8(21.1)$ & 7 (18.4) & $5(13.2)$ & $10.91(0.20)$ \\
\hline $\begin{array}{l}\text { I had adequate opportunities for } \\
\text { hands-on clinical work (eg, active } \\
\text { involvement in the clinics or ORs, } \\
\text { case presentation, etc). }\end{array}$ & $2.86 \pm \mid .31$ & $5(13.2)$ & $8(21.1)$ & $9(23.7)$ & 9 (23.7) & $7(18.4)$ & $7.04(0.53)$ \\
\hline $\begin{array}{l}\text { The elective provided me an } \\
\text { appropriate amount of responsibility } \\
\text { to match my current clinical skills. }\end{array}$ & $2.84 \pm 0.94$ & $0(0)$ & II (28.9) & $13(34.2)$ & II (28.9) & $3(7.9)$ & $8.67(0.19)$ \\
\hline $\begin{array}{l}\text { The elective provided me an } \\
\text { active learning through discussion/ } \\
\text { participation? }\end{array}$ & $3.21 \pm 1.09$ & $3(7.9)$ & I4 (36.8) & $3(34.2)$ & $4(10.5)$ & $4(10.5)$ & $\begin{array}{l}13.60 \\
(0.09)\end{array}$ \\
\hline $\begin{array}{l}\text { If you agree with the question above, } \\
\text { do you think the level of discussion } \\
\text { was above your knowledge level? }\end{array}$ & $2.89 \pm 1.18$ & $2(5.3)$ & $13(34.2)$ & $7(18.4)$ & II (28.9) & $5(13.2)$ & $4.14(0.84)$ \\
\hline $\begin{array}{l}\text { The elective contributed to my } \\
\text { overall professional development. }\end{array}$ & $3.36 \pm 1.17$ & $6(15.8)$ & $14(36.8)$ & $9(23.7)$ & $6(15.8)$ & $3(7.9)$ & $8.06(0.42)$ \\
\hline The elective met my expectations? & $3.57 \pm 1.32$ & $12(31.6)$ & II (28.9) & $5(13.2)$ & $7(18.4)$ & $3(7.9)$ & $\begin{array}{l}15.54 \\
(0.04)\end{array}$ \\
\hline $\begin{array}{l}\text { The elective was a good use of time } \\
\text { for me during medical school. }\end{array}$ & $3.18 \pm 1.39$ & $8(2 I . I)$ & $10(26.3)$ & $7(18.4)$ & $7(18.4)$ & $6(15.8)$ & $\begin{array}{l}10.97 \\
(0.20)\end{array}$ \\
\hline $\begin{array}{l}\text { The elective helped me in choosing } \\
\text { my future specialty? }\end{array}$ & $3.21 \pm 1.37$ & $9(23.7)$ & $8(21.1)$ & $8(21.1)$ & $8(21.1)$ & $5(13.2)$ & $7.77(0.45)$ \\
\hline $\begin{array}{l}\text { The elective helped me in excluding } \\
\text { a specialty? }\end{array}$ & $3.28 \pm 1.38$ & $9(23.7)$ & $8(21.1)$ & II (28.9) & $5(13.2)$ & $5(13.2)$ & $\begin{array}{l}10.08 \\
(0.25)\end{array}$ \\
\hline $\begin{array}{l}\text { The elective helped me in deciding } \\
\text { different aspects of my future career? } \\
\text { *eg, Master programs, fellowships etc. }\end{array}$ & $3.42 \pm 1.17$ & $7(18.4)$ & $13(34.2)$ & $10(26.3)$ & $5(13.2)$ & $3(7.9)$ & $8.93(0.34)$ \\
\hline $\begin{array}{l}\text { My experience encouraged me to go } \\
\text { abroad for residency or fellowship. }\end{array}$ & $3.63 \pm 1.34$ & $13(34.2)$ & $10(26.3)$ & $7(18.4)$ & $4(10.5)$ & $4(10.5)$ & $5.29(0.72)$ \\
\hline $\begin{array}{l}\text { The elective helped me to learn how } \\
\text { to deal with a different culture? }\end{array}$ & $4.60 \pm 0.71$ & $27(7 I . I)$ & $8(21.1)$ & $2(5.3)$ & I (2.6) & $0(0)$ & $5.00(0.54)$ \\
\hline $\begin{array}{l}\text { The elective helped me to learn } \\
\text { how to deal with a different working } \\
\text { environment? }\end{array}$ & $4.47 \pm 0.76$ & $23(60.5)$ & II (28.9) & $3(7.9)$ & $\mathrm{I}(2.6)$ & $0(0)$ & $2.68(0.84)$ \\
\hline
\end{tabular}

Abbreviation: OR, operating room.

(63.2\%), traveled alone for the elective course from Saudi Arabia. All $38(100 \%)$ of the students participating in this survey agreed that about "someone was assigned to assist me" (during my elective abroad). Regarding the survey item, "country of elective", 18 (47.36\%) had their elective in Korea, 13 (34.21\%) in Canada, 4 (10.52\%) in France, and 3 (7.89\%) in the UK. 
Table 4 Responses concerning students' future recommendations about the elective

\begin{tabular}{|c|c|c|c|}
\hline Item & Categories & $\begin{array}{l}\text { Number } \\
\text { (\%) }\end{array}$ & Student responses (why or why not) \\
\hline $\begin{array}{l}\text { Would you } \\
\text { recommend this } \\
\text { elective to other } \\
\text { medical students? }\end{array}$ & $\begin{array}{l}\text { Yes } \\
\text { No }\end{array}$ & $\begin{array}{l}30 \text { (78.9) } \\
8(21.1)\end{array}$ & $\begin{array}{l}\text { A great opportunity to experience a different work environment, new } \\
\text { modalities in surgeries, be familiar with cultural differences. It was an } \\
\text { experience of a lifetime to get to practice plastic surgery in such a pioneer } \\
\text { institute along with professors who created the field! Very inspiring and } \\
\text { useful. Also, the cases seen there are mostly rare syndromes and complex } \\
\text { conditions, which adds to my professional experience. Reconstructive } \\
\text { surgery elective in Asan is a highly recommended experience that adds to } \\
\text { your overall development. Each postoperative patient is a living piece of } \\
\text { art! It is truly fascinating! } \\
\text { It is really poor from an academic point. The language barrier is huge; } \\
\text { unless your Korean language is good you will be separated from everything } \\
\text { as English is not at all used by the staff nor patients even the files and } \\
\text { medical records are in Korean. It is a cultural reservoir; however, very } \\
\text { limited academic benefit due to lack of communication with supervisors } \\
\text { and patients due to language barriers. Because I couldn't do any } \\
\text { examination or take history, the professor was busy and couldn't teach me. }\end{array}$ \\
\hline
\end{tabular}

Table 3 summarizes the students' perception about the elective course. The overall mean of all items was $3.48 \pm 0.51$. Half of the total participating students, ie, 19 (50\%), agreed that adequate information was provided to in advance as to what to expect during the elective course. Similarly, most of the students, ie, 25 (65.7\%), agreed that the objective of the elective course was clear to them in advance. Twenty-seven (71.1\%) of students agreed that the program (elective) was responsive to their needs (both academically and socially). Eighteen (47.3\%) of students agreed that they had adequate supervision of clinical training during the elective course. A further comparative analysis found that $16(42.1 \%)$ of the participants disagreed about "I had adequate opportunities for hands-on clinical work." About the survey item, "elective provided for me an active learning through discussion/participation," 17 (44.7\%) of the students agreed, and the correlation between males and females were not significant. The majority of students, 18 (47.4\%), agreed that this elective course was a good use of time during my academic years in the medical school. Furthermore, $23(60.5 \%)$ of students reported that elective meet their expectation, and correlation between males and females was statically significant $(P=0.04)$.

\section{Description and aspects (qualitative analysis)}

A good number of a student's response with their written comments was recorded (against the open-ended question). Table 4 highlights students' description about electives, with the total $30(78.9 \%)$ students commenting on it as "I recommend this elective to other medical students". The responses of some students were as follows:

A great opportunity to experience a different work environment, new modalities in surgeries, to be familiar with cultural differences.

It was an experience of a lifetime to get to practice plastic surgery in such a pioneer institute along with professors who created the field.

Very inspiring and useful.

Reconstructive surgery elective at a medical center in Asan is a highly recommended experience that adds to your overall development.

There were also 8 (21.1\%) students who disagreed with regard to this item, I recommend this elective to other medical students." The responses from such students were follows:

It is really poor from an academic point.

Very limited academic benefit due to lack of communication with supervisors and patients due to language barriers.

I couldn't do any examination or taking a history, the professor was busy and couldn't teach me.

\section{Discussion}

Electives have been designated as a foundation of "transferable skills." ${ }^{\prime 4}$ They have been revealed to help medical students familiarize themselves with modification and cope with new and uncertain circumstances, especially as they allow the addition of different study courses among different 
learners. The objectives of undergraduate medical education are characterized not only as "knowledge objectives" and "skills objectives" but also "attitudinal objectives" which may be encouraged by such an elective program. ${ }^{15}$

We found that students agreed that their learning was optimized through the active learning component associated with the electives. A similar finding was recorded in a local study, where students stressed the need for active learning for achieving and sustaining the higher grades in their studies and tests. ${ }^{16}$ The electives also increased medical student knowledge in the areas, outside of the traditional medical school curriculum, taught medical students valuable skills, escalated student wellness, and influenced ultimate career selections. The medical curriculum has to be changed for optimized standards; so, establishing institutional programs and structures that foster learning is essentially inevitable. ${ }^{17}$ Each perception that we explored worked in order to inform readers as well as enabled us to devise future internal changes. However, we did find great variation in the students' perception toward the electives. Most elective courses are established jointly by medical students and faculty who are passionate about certain areas of the undergraduate topics, not fully covered in the traditional medical curriculum.

This paper successfully determined that undergraduate medical students in the College of Medicine are profiting from the elective program as much as they should be.

Quantitative findings established steady patterns of elective selection among different year cohorts. This finding may specify that medical students' desire to choose electives directly linked to their course.

The responses of the participants to open-ended questions toward the elective program were varied, with a blend of eagerness and frustration. When asked if they would recommend this elective to other colleagues, the majority agreed with varied and interesting replied saying, "A great opportunity to experience a different work environment", "new modalities in surgeries", "It was an experience of a lifetime to get to practice plastic surgery in such a pioneer institute". We found that our students also mentioned, "it's great to be familiar with cultural differences". A similar finding was recorded which stated that cultural competence has been associated with cultural awareness. ${ }^{18}$ It was projected during the study that the nature of this undergraduate medical elective program impacted meaningfully on both the understanding of the subjects and future directions for training the learners. In addition, the electives demonstrated increases in students' self-reported confidence in their clinical skills. ${ }^{19-22}$
Finally, there was a positive significance in the fact that attitudes to the elective program were mainly positive, with the majority of students indicating a preference to recommend it to others.

\section{Study limitations}

The main limitation of this study is the small sample. It did not take into account students' personal demographics other than gender. The qualitative study involved was purely based on open-ended question remarks and could have been better improved with the advanced modality of interviewing the students. Although the reappearance of key ideas and the consistency between responses suggested a considerable degree of inundation, the authors felt that the sample size was smaller than anticipated.

\section{Conclusion}

These electives play a significant role in medical students' education by increasing medical student knowledge in zones outside of the traditional curriculum, teaching medical students valued skills, escalating student wellness, and effecting ultimate career selections. We strongly believe electives at College of Medicine, KSU, do have a quantifiable, positive influence on students' understanding of the medical subjects, and therefore can be a valuable supplement to the formal curriculum. This should also be a priority for other medical institutes within the region for training their students augmented by elective. We, therefore, believe that it is the need of the hour to provide support for the students interested in undergoing preclinical electives.

\section{Recommendation}

Institution-explicit recommendations from this study are as follows. The orientation sessions for the students should be organized more frequently with the help of advanced tools, eg, an online tool for elective selection to improve accessibility. The elective program should be advertised more prominently and should be offered to the students at an early stage of their academic year, ie, 1st, 2nd, and 3rd year. To achieve this, it is recommended that a thorough review of the enrollment strategy for elective modules be carried out.

\section{Acknowledgment}

The authors thank all the students who took part in responding to the questionnaire and recognize the appropriate issues connected with the international health electives. 


\section{Disclosure}

The authors report no conflicts of interest in this work.

\section{References}

1. Wershof Schwartz A, Abramson JS, Wojnowich I, Accordino R, Ronan EJ, Rifkin MR. Evaluating the impact of the humanities in medical education. Mt Sinai J Med. 2009;76(4):372-380.

2. Stys D, Hopman W, Carpenter J. What is the value of global health electives during medical school? Med Teach. 2013;35(3):209-218.

3. Mookherjee S, Ranji S, Neeman N, Sehgal N. An advanced quality improvement and patient safety elective. Clin Teach. 2013;10(6):368-373.

4. Association of American Medical Colleges. Medical School Graduation Questionnaire Report. Washington, DC: Division of Medical Education, Association of American Medical Colleges; 2000.

5. Dodard M, Vulcain A, Fournier A. Project Medishare: a volunteer program in international health at the University of Miami. Acad Med. 2000;75(4):397-401.

6. Weir E. A summer in India. Can Med Assoc J. 1996;155:785-787.

7. Imperato PJ. A Third World international health elective for U.S. medical students. The 16-year experience of the State University of New York, Health Science Center at Brooklyn. J Community Health. 1996;21(4):241-268.

8. Bateman C, Baker T, Hoornenborg E, Ericsson U. Bringing global issues to medical teaching. Lancet. 2001;358(9292):1539-1542.

9. Kumwenda B, Dowell J, Daniels K, Merrylees N. Medical electives in sub-Saharan Africa: a host perspective. Med Educ. 2015;49(6):623-633.

10. Dowell J, Merrylees N. Electives: isn't it time for a change? Med Educ. 2009;43(2):121-126.

11. Rahim A, Knights Née Jones F, Fyfe M, Alagarajah J, Baraitser P. Preparing students for the ethical challenges on international health electives: A systematic review of the literature on educational interventions. Med Teach. 2016;38(9):911-920.
12. Purcell P, Dunnion J, Loughran H. Patterns of Elective Choice in the University College Dublin Undergraduate Curriculum. In: International Conference on Engaging Pedagogy 2010; September 2; 2010; Maynooth, Ireland. National University of Ireland Maynooth; CICEP10.

13. Dunnion J, Purcell P, Loughran H. Experiences of Elective Provision at UCD. Available from: http://icep.ie/wp-content/uploads/2013/12/ DunnionPurcellLoughran.pdf. Accessed September 1, 2017.

14. Harden RM, Davis MH. Medical Education Guide No. 5. The Core Curriculum with Options or Special Study Modules. 2nd ed. Dundee, Scotland: The Association for Medical Education in Europe; 2001.

15. General Medical Council. Tomorrow's Doctors: Recommendations on Undergraduate Medical Education. London: General Medical Council; 1993.

16. Sattar K, Ahmad T, Khalil MS, Soliman MM, Punnamperuma GG, Abdulghani HM. Medical students' perception of the progress test as a quality-controlled assessment tool for improving learning and teaching, at a public sector medical college in Saudi Arabia. JPMA. 2017:300-304.

17. Haramati A. Educating the educators: a key to curricular integration. Acad Med. 2015;90(2):133-135.

18. Rew L, Becker H, Cookston J, Khosropour S, Martinez S. Measuring cultural awareness in nursing students. J Nurs Educ. 2003;42(6):249-257.

19. Chapman JJ, Weiss SJ, Haynes ML, Ernst AA. Impact of EMS education on emergency medicine ability and career choices of medical students. Prehosp Emerg Care. 1999;3(2):163-166.

20. Keating EM, O'Donnell EP, Starr SR. How we created a peer-designed specialty-specific selective for medical student career exploration. Med Teach. 2013;35(2):91-94.

21. Leschied JR, Knoepp US, Hoff CN, et al. Emergency radiology elective improves second-year medical students' perceived confidence and knowledge of appropriate imaging utilization. Acad Radiol. 2013;20(9):1168-1176.

22. Purkey E, Hollaar G. Developing consensus for postgraduate global health electives: definitions, pre-departure training and post-return debriefing. BMC Med Educ. 2016;16(1):159.
Advances in Medical Education and Practice

\section{Publish your work in this journal}

Advances in Medical Education and Practice is an international, peerreviewed, open access journal that aims to present and publish research on Medical Education covering medical, dental, nursing and allied health care professional education. The journal covers undergraduate education, postgraduate training and continuing medical education

\section{Dovepress}

including emerging trends and innovative models linking education, research, and health care services. The manuscript management system is completely online and includes a very quick and fair peer-review system. Visit http://www.dovepress.com/testimonials.php to read real quotes from published authors. 